\title{
Complement-induced $\mathrm{Ca}^{2+}$ influx in cultured fibroblasts is decreased by the calcium-channel antagonist nifedipine or by some bivalent inorganic cations
}

\author{
Philip NEWSHOLME, ${ }^{\star}$ Azubueze A. ADOGU, Maria A. SOOS and C. Nicholas HALES \\ Department of Clinical Biochemistry, University of Cambridge, Addenbrooke's Hospital, Hills Road, Cambridge CB2 2QR, U.K.
}

The effects of different extracellular cations or organic $\mathrm{Ca}^{2+}$ channel modulators on complement-induced changes in intracellular $\mathrm{Ca}^{2+}$ and cell death have been investigated in the transfected NIH-3T3 HIR 3.5 cell line, which overexpresses the human insulin receptor. Cells were incubated with mouse anti(human insulin receptor) monoclonal antibodies before exposure to rabbit or human serum (sources of heterologous complement). Changes in intracellular $\mathrm{Ca}^{2+}$ were complement-dependent (measured by influx of ${ }^{45} \mathrm{Ca}$ ), as was cytotoxicity (monitored by leakage of lactate dehydrogenase into the culture supernatant). Addition of a dihydropyridine $\mathrm{Ca}^{2+}$-channel antagonist (nifedipine) or some bivalent inorganic cations caused inhibition of
${ }^{45} \mathrm{Ca}$ entry via a novel channel distinct from endogenous voltagegated $\mathrm{Ca}^{2+}$ channels. Nifedipine decreased, but conversely the addition of a phenylalkylamine $\mathrm{Ca}^{2+}$-channel antagonist (verapamil) or the inorganic $\mathrm{Ca}^{2+}$ agonists $\mathrm{Ba}^{2+}$ and $\mathrm{Sr}^{+}$increased, complement-induced cytotoxicity. These agents had no effect on cell viability at the studied concentrations, in the absence of complement. It is concluded that complement-induced cytotoxicity is mediated by $\mathrm{Ca}^{2+}$ influx through novel specific transmembrane channels which are sensitive to the $\mathrm{Ca}^{2+}$-channel antagonist nifedipine, but otherwise show little resemblance to L- or T-type voltage-gated $\mathrm{Ca}^{2+}$ channels.

\section{INTRODUCTION}

The membrane attack complex (MAC), formed by the selfpolymerization of the terminal components of the complement cascade, binds to the surfaces of appropriate target cells and has been suggested to effect cytolysis by forming transmembrane pores [1,2]. An alternative hypothesis is that of Esser, who has suggested a 'leaky patch' formation in the vicinity of MAC [3]. However, Esser's group has recently published data showing the formation of single channels by MAC in artificial bilayer membranes [4], data which support other recent work showing single channel formation by MAC [5,6]. These studies have indicated that there is selectivity for cations over anions upon formation of the channel. It is thought that the binding and insertion of complement component $\mathrm{C} 9$ to the membraneattached $\mathrm{C} 5 \mathrm{~b}-8$ complex is responsible for the actual pore formation [7].

The mechanism of MAC-induced cell death is uncertain, though it has been shown that MAC insertion is associated with a transient $\mathrm{Ca}^{2+}$ influx and increased cytosolic $\mathrm{Ca}^{2+}$ concentration [8-10], which may be followed by large membrane permeability changes [11] and cell death. However, the transient rise in intracellular $\mathrm{Ca}^{2+}$ may be followed by cell recovery via MAC shedding in the case of neutrophils, oligodendrocytes and platelets [10-12]. It is possible that a rise in intracellular $\mathrm{Ca}^{2+}$ is, under certain circumstances (e.g. higher complement concentrations) ultimately responsible for cell lysis. Free intracellular $\mathrm{Ca}^{2+}$ ions act as intracellular regulators of cell function [13], and excessive increases in intracellular concentration may precipitate cell death by a multitude of events, including activation or inhibition of key enzymes, organelle disruption, protein denaturation and depletion of ATP. More specifically, phospholipase activation would stimulate membrane breakdown and loss of ionic gradients [14], and $\mathrm{Ca}^{2+}$-induced dissipation of mitochondrial membrane potential would consequently block oxidative phosphorylation
[15]. Cellular ATP content would subsequently fall, and original ionic gradients across the plasma membrane will not be regenerated; thus depolarization of the cell membrane will occur, eventually leading to larger permeability changes, osmotic lysis and cell death. The requirement for $\mathrm{Ca}^{2+}$ in the complementmediated lytic process has still not been proved, and it is still widely believed that MAC is a rigid hollow structure, like a doughnut [1], that produces a general ion influx followed by colloid osmotic lysis. However, various studies using alternative lytic stimulators have confirmed, for example, that the lethal effect of A23187 is due to the rise in intracellular $\mathrm{Ca}^{2+}$ [16] (an essential event that appears to represent a final common pathway in toxic cell death [17]. Early complement studies [18,19] have shown that, if high concentrations of EDTA $(30$ or $90 \mathrm{mM}$ ) are added to cells after reaction with complement, then lysis was blocked. However, use of chelating agents at such high concentrations makes clear interpretations of results difficult.

We have used cultured NIH 3T3 HIR 3.5 cells, which express high levels of the human insulin receptor [20], and complementfixing anti-(insulin receptor) monoclonal antibodies [21] as a model system in which to investigate $\mathrm{Ca}^{2+}$ influx during complement-mediated cell attack, possible blocking agents of this ion influx, and whether $\mathrm{Ca}^{2+}$ entry is a key event in stimulating cell lysis.

\section{MATERIALS AND METHODS}

\section{Reagents, cells, culture media}

Tissue-culture medium, supplements and sterile plasticware were obtained from Gibco, Paisley, Scotland, U.K. Intravenous-grade nifedipine was obtained from Bayer (Newbury, Berks, U.K.), and stored in the dark at $4{ }^{\circ} \mathrm{C}$ until use. Unless otherwise stated, all other chemicals were purchased from Sigma Chemical Co. (Poole, Dorset, U.K.), BDH Chemicals (Poole, Dorset, U.K.), Roche Products (Welwyn, Herts., U.K.) and SmithKline

Abbreviations used: MAC, membrane attack complex; DMEM, Dulbecco's modified Eagle's medium; LDH, lactate dehydrogenase.

* To whom all correspondence should be sent. Present address: Department of Biochemistry, University College Dublin, Belfield, Dublin 4, Ireland. 
Beecham (Welwyn, Herts., U.K.). The NIH 3T3 HIR 3.5 mouse fibroblast cell line was kindly given by Dr. J. Whittaker [20].

NIH-3T3 $3.5 \mathrm{HIR}$ cells were propagated in $75 \mathrm{~cm}^{2}$ tissueculture flasks containing Dulbecco's modified Eagle's medium (DMEM) supplemented with $10 \%$ (v/v) fetal-calf serum, $2 \mathrm{mM}$ glutamine, $50 \mathrm{i} . \mathrm{u} . / \mathrm{ml}$ penicillin and $50 \mu \mathrm{g} / \mathrm{ml}$ streptomycin. The cells were cultured in an atmosphere of air $/ \mathrm{CO}_{2}(19: 1)$ within a humidified tissue-culture incubator at $37^{\circ} \mathrm{C}$. The culture medium was changed every 3 days, and cells were serially passaged on attaining $\sim 80 \%$ confluence.

The serum used for a source of complement for these studies was derived from non-immune Dutch rabbits or from a human source (P.N.). The blood was allowed to clot at room temperature for $45 \mathrm{~min}$, and was then centrifuged at $980 \mathrm{~g}$ for $20 \mathrm{~min}$. Serum was stored at $-70^{\circ} \mathrm{C}$ for up to 1 month before use.

\section{Antibodies}

The anti-(human insulin receptor) mouse monoclonal antibodies 18-44 and 83-14, which were of the IgG2b and IgG2a isotypes [21] respectively, were purified from ascites fluid by $\left(\mathrm{NH}_{4}\right)_{2} \mathrm{SO}_{4}$ precipitation, followed by chromatography on a hydroxyapatite column as described previously [22]. A mouse IgG1 anti-insulin antibody, 14B [21], and a mouse IgG1 monoclonal antibody recognizing an intracellular epitope on the b-chain of the human insulin receptor, CT1 [21], were used as negative controls. Preliminary experiments were performed to determine which were the most cytotoxic anti-insulin-receptor antibodies from the batch initially provided, as well as the most potent serum dilutions to use with these antibodies [23].

\section{Complement cytotoxicity assay}

In the standard procedure, NIH-3T3 3.5 HIR cells were seeded into 24-well culture dishes at a cell density of $5 \times 10^{4}$ cells/well, and allowed to reach $\sim 80 \%$ confluence over $48 \mathrm{~h}$. The cells were rinsed twice with DMEM (without fetal-calf serum), before incubation with $300 \mu \mathrm{l}$ of $40 \mathrm{nM}$ antibody in DMEM for $30 \mathrm{~min}$ at $37^{\circ} \mathrm{C}$. The cells were rinsed again with DMEM to remove unbound antibody, before incubation at $37^{\circ} \mathrm{C}$ for $60 \mathrm{~min}$ in $300 \mu \mathrm{l}$ of non-immune rabbit serum, diluted $1: 5$ in a Hepes buffer (containing $88 \mathrm{mM} \mathrm{NaCl}, 2 \mathrm{mM} \mathrm{KCl}, 2.4 \mathrm{mM} \mathrm{NaHCO}$, $2 \mathrm{mM} \mathrm{MgCl} 2,2 \mathrm{mM} \mathrm{CaCl}$ and $15 \mathrm{mM}$ Hepes, $\mathrm{pH}$ 7.4). The reaction was rapidly terminated by transferring the plates to an ice chamber. Supernatant $(200 \mu \mathrm{l})$ was removed from each well, centrifuged at $500 \mathrm{~g}$ for $10 \mathrm{~min}$ to remove cell debris and stored at $-70^{\circ} \mathrm{C}$ until required. Lactate dehydrogenase (LDH) assays were performed in triplicate to assess cell viability, by the method of Wroblewski and Ladue [24]. For the assessment of spontaneous LDH release, the supernatant obtained from target fibroblasts incubated with control antibodies/rabbit serum was similarly assayed. Total LDH was measured after lysis of parallel wells by $15 \mathrm{~s}$ sonication in lysis buffer [containing $50 \mathrm{mM}$ Hepes, $\mathrm{pH} 7.6,30 \mathrm{mM}$ sodium pyrophosphate, $10 \mathrm{mM}$ EDTA, $10 \mathrm{mM}$ NaF, $1 \%(w / v)$ BSA, $1 \%(w / v)$ Triton X-100, 1 mM phenylmethanesulphonyl fluoride, $20 \mathrm{mM}$ leupeptin, $100 \mathrm{mM}$ transepoxysuccinyl-L-leucylamido(4-guanidino)butane]. Percentage LDH release (as a measure of cytotoxity) was calculated by the formula :

$$
\begin{aligned}
& \text { LDH release }(\%)= \\
& 100 \times \frac{\text { experimental release }- \text { spontaneous release }}{\text { total LDH content of target cells }} .
\end{aligned}
$$

\section{Correlation of LDH release with Trypan Blue exclusion}

After incubation of antibody-coated target cells with complement, both LDH assays and Trypan Blue dye exclusion were performed to determine the correlation of enzyme leakage with residual cell viability. LDH release into the supernatant showed a close positive correlation with Trypan-Blue dye staining (correlation coefficient, $r=0.97$ ).

\section{Measurement of ${ }^{45} \mathrm{Ca}$ uptake}

3T3 HIR cells were cultured and seeded into 24-well culture dishes as described above. Before addition of ${ }^{45} \mathrm{Ca}^{2+}$, cells were incubated with $300 \mu \mathrm{l}$ of $40 \mathrm{nM}$ antibody 83-14 in DMEM for $30 \mathrm{~min}$ at $37^{\circ} \mathrm{C}$. The cells were rinsed again with DMEM to remove unbound antibody, before incubation at $37^{\circ} \mathrm{C}$ in $300 \mu \mathrm{l}$ of human serum (source, P.N.) diluted 1:5 in a Hepes buffer (containing $88 \mathrm{mM} \mathrm{NaCl}, 2 \mathrm{mM} \mathrm{KCl}, 2.4 \mathrm{mM} \mathrm{NaHCO}, 2 \mathrm{mM}$ $\mathrm{MgCl}_{2}, 2 \mathrm{mM} \mathrm{CaCl}{ }_{2}$ and $15 \mathrm{mM}$ Hepes, $\mathrm{pH}$ 7.4), but with the addition of $6.5 \mu \mathrm{Ci}$ of ${ }^{45} \mathrm{Ca}$ per well. At the end of the incubation period, cells were washed four times with buffer (minus ${ }^{45} \mathrm{Ca}$ ) and then lysed by addition of buffer $+1 \%$ Triton X-100, followed by sonication. Cellular debris was removed by centrifugation, and the radioactivity in the supernatant was measured with a Packard Tri-Carb 1500 liquid-scintillation counter.

\section{Pathway of complement activation}

Antibody 18-44 (300 $\mu \mathrm{l}$ of $10 \mathrm{nM}$ ) was added to NIH 3T3 HIR 3.5 cells, and incubated as described above. Thereafter, target cells were further exposed to $300 \mu \mathrm{l}$ of non-immune rabbit serum diluted in Hepes buffer at $37^{\circ} \mathrm{C}$ for $60 \mathrm{~min}$. Parallel samples using rabbit serum preheated at $50^{\circ} \mathrm{C}$ for $15 \mathrm{~min}$ to inactivate factor B [25] were set up, and incubated as described above. The supernatants were removed for LDH assay at the termination of incubation.

\section{Effects of channel modulators on cell lysis}

All drug-containing media used for experimentation were prepared from fresh aqueous stock solutions. Non-immune rabbit or human serum as a source of complement was added to the Hepes buffer described above containing the various agents under test at specified concentrations. Each drug, diluted in buffer, was also tested in the absence of serum over $100 \mathrm{~min}$, to exclude an independent non-immune cytotoxic effect on target cells.

For experiments where inorganic ions were substituted for $\mathrm{Ca}^{2+}$, rabbit serum was diluted as described in $\mathrm{Ca}^{2+}$-free Hepes buffer, $\mathrm{Ca}^{2+}$ being replaced by $\mathrm{Mn}^{2+}, \mathrm{Ni}^{2+}, \mathrm{Sr}^{2+}, \mathrm{Ba}^{2+}, \mathrm{La}^{2+}, \mathrm{Co}^{2+}$ $\mathrm{Cd}^{2+}, \mathrm{Zn}^{2+}, \mathrm{Cu}^{2+}$ and $\mathrm{Mg}^{2+}$ (as the chloride salts). The final concentration of $\mathrm{Ca}^{2+}$ (derived from serum) was approx. $0.3 \mathrm{mM}$ in these experiments.

\section{Presentation of data}

Results presented, unless indicated otherwise, are as means \pm S.D. of quadruplicate wells, and are representative of at least three separate experiments.

\section{RESULTS}

The classical pathway of complement activation elicits $\mathrm{Ca}^{2+}$ entry into and LDH release from 3T3 HIR cells

LDH release in antibody-coated fibroblasts was found to be dependent on the activation of the classical pathway of complement (Figure 1). Destruction of Factor B (and thus the 


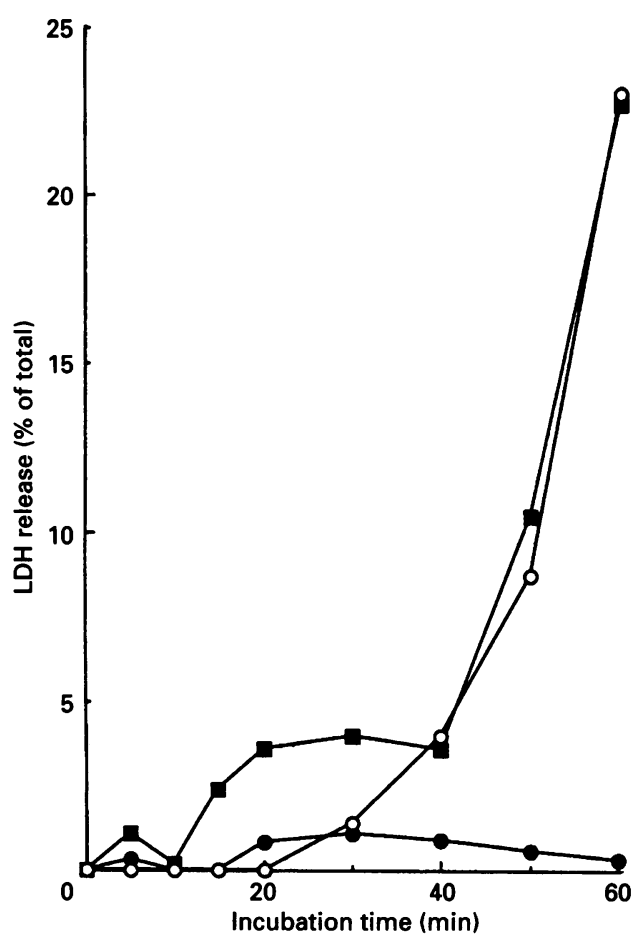

Figure 1 Pathway of complement activation

LDH release from $3 T 3$ HIR cells (as \% of total cell LDH) was measured in culture supernatant as described in the Materials and methods section, after exposure to antibody and diluted rabbit serum ( $\boldsymbol{\square}$ ) or rabbit serum preheated at $50^{\circ} \mathrm{C}$ for 15 min to inactivate factor $B$ before dilution in Hepes buffer $(O)$ or rabbit serum diluted in $\mathrm{Ca}^{2+}$-chelated Hepes buffer, containing $10 \mathrm{mM}$ EGTA/7 $\mathrm{mM} \mathrm{Mg}^{2+}$ to allow activation of the alternative pathway while inhibiting the classical pathway (O). The S.D. at each point was less than $3.5 \%$ of the mean value.

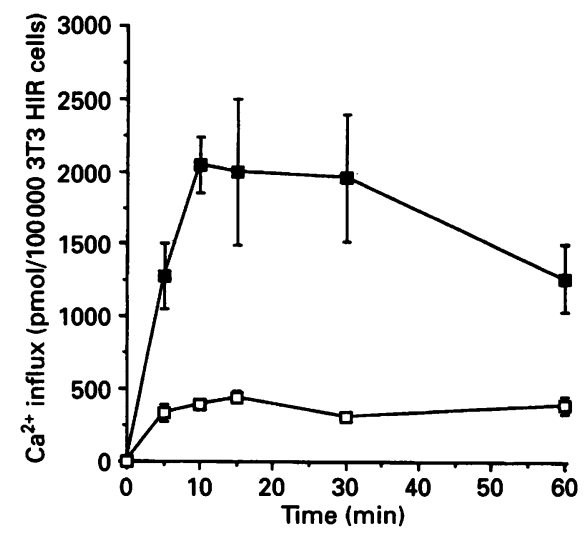

Figure 2 Effect of human serum on ${ }^{45} \mathrm{Ca}^{2+}$ uptake

Antibody-coated $3 T_{3}$ fibroblasts were incubated in the presence of 5 -fold-diluted human serum treated at $50{ }^{\circ} \mathrm{C}$ for $15 \mathrm{~min}$ to inhibit the alternative pathway $(\boldsymbol{\square})$, or at $56{ }^{\circ} \mathrm{C}$ for $30 \mathrm{~min}$ to inhibit both complement-activation pathways $(\square)$. There was no significant difference between the results obtained by using serum treated at $50^{\circ} \mathrm{C}$ for $15 \mathrm{~min}$ or those obtained by using untreated serum (results not shown). Methods have been described previously.

alternative pathway of activation) by treating the serum at $50^{\circ} \mathrm{C}$ for $15 \mathrm{~min}$ [25] did not inhibit LDH release at the 40 and $60 \mathrm{~min}$ time points. The fact that there was no difference in $\mathrm{LDH}$ release at these time points between untreated and $50^{\circ} \mathrm{C}$-heated serum suggests that the classical pathway is solely responsible for lysis.

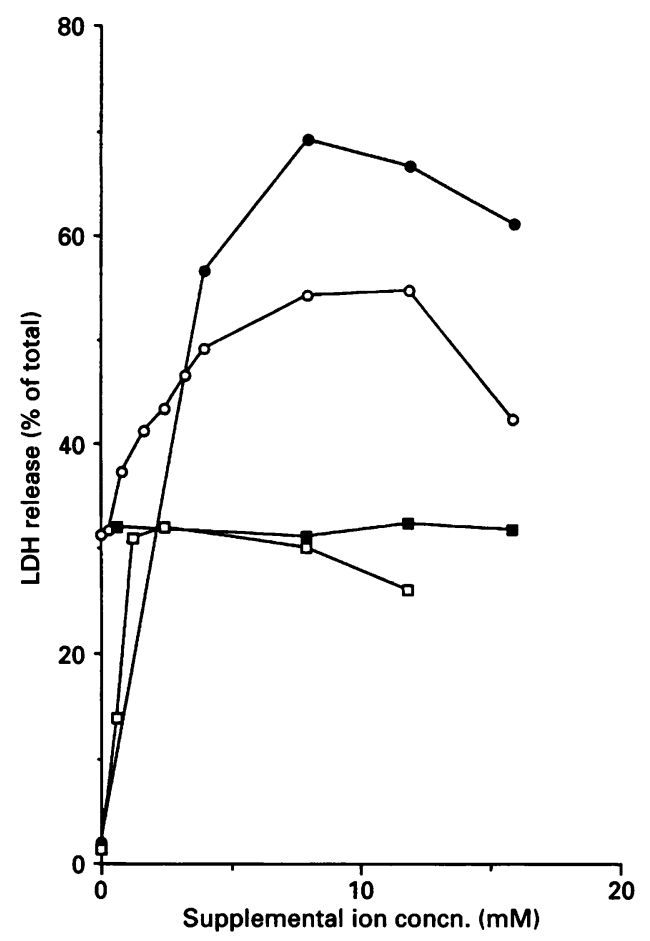

Figure 3 Effects of cation concentration on cytotoxiclity

Antibody-coated fibroblasts were incubated in Hepes buffer with final concentrations of either $\mathrm{Ca}^{2+}(\square)$ or $\mathrm{K}^{+}(\square)$ altered over a total range of $0-17 \mathrm{mM}$, as described in the Materials and methods section. $\mathrm{Ba}^{2+}$ concentrations were similarly altered in both $\mathrm{Ca}^{2+}$-free $(\mathbf{O})$ and normal $(O)$ Hepes buffer over a similar concentration range, and complement-induced cytotoxicity was assessed as described previously, in quadruplicate wells (S.D. of mean at each point less than $3.5 \%$ ). Osmolarity was maintained in each case by adjusting the $\mathrm{NaCl}$ concentration appropriately.

The addition of $10 \mathrm{mM} \mathrm{EGTA}+7 \mathrm{mM} \mathrm{MgCl} \mathrm{m}_{2}$ to the buffer used to dilute the rabbit serum (which allowed alternative-pathway activation while inhibiting the classical pathway) resulted in inhibition of LDH release. The implication of this result is addressed in the Discussion section, as it provides evidence for the essential role of $\mathrm{Ca}^{2+}$ in the lytic process. $\mathrm{LDH}$ release after 60 min was relatively low in this experiment, compared with those shown in Figures 3 and 5 and Table 1. This finding may have been a consequence of switching from New Zealand White rabbit to Dutch rabbit serum for the latter experiments.

$\mathrm{Ca}^{2+}$ entry into 3T3 HIR cells was also stimulated by the classical pathway of complement activation (Figure 2). Complete destruction of heat-labile proteins in both complement-activation pathways by treating serum at $56^{\circ} \mathrm{C}$ for 30 min [26] resulted in low fluxes of $\mathrm{Ca}^{2+}$ into these cells. Rabbit serum treated at $56^{\circ} \mathrm{C}$ for $30 \mathrm{~min}$ to inactivate complement [26] totally abolished LDH release from the 3T3 HIR cells over the $60 \mathrm{~min}$ incubation period (results not shown).

\section{Effects of blvalent cations on ${ }^{45} \mathrm{Ca}$ entry and LDH release}

There was a concentration-dependent increase in LDH release with increasing extracellular $\mathrm{Ca}^{2+}$ (Figure 3). A similar cytotoxicity profile was observed with the $\mathrm{Ca}^{2+}$ agonist $\mathrm{Ba}^{2+}$, though this had a higher peak than $\mathrm{Ca}^{2+}$ alone, which was diminished by addition of $2.0 \mathrm{mM} \mathrm{Ca}^{2+}$. It is known that $\mathrm{Ba}^{2+}$ can replace $\mathrm{Ca}^{2+}$ as a charge carrier and that it has a greater conductance through L-type calcium channels [27]. Conversely, there was no significant 


\section{Table 1 Effect of inorganic cations on cytotoxiclty}

Experimental details are given in the Materials and methods section. 3T3 HIR cells were incubated over $60 \mathrm{~min}$ in 5-fold-diluted rabbit serum diluted in the standard buffer minus $\mathrm{Ca}^{2+}$ The ions listed below were added at a final concentration of $3 \mathrm{mM}$. The results expressed are normalized to the LDH release occurring in the presence of $\mathrm{Ca}^{2+}$ only. This was $38 \%$ of tota cellular LDH. S.E.M. was less than $10 \%$ of the mean value for all results shown $(n=9)$. The final $\mathrm{Ca}^{2+}$ concentration in all but the $\mathrm{Ca}^{2+}$-only condition was $0.3 \mathrm{mM}$.

\begin{tabular}{ll}
\hline Inorganic cation & LDH release (\%) \\
\hline $\mathrm{Ba}^{2+}$ & 176 \\
$\mathrm{Sr}^{2+}$ & 155 \\
$\mathrm{Ca}^{2+}$ & 100 \\
$\mathrm{La}^{3+}$ & 71 \\
$\mathrm{Co}^{2+}$ & 50 \\
$\mathrm{Cd}^{2+}$ & 32 \\
$\mathrm{Mn}^{2+}$ & 31 \\
$\mathrm{Ni}^{2+}$ & 13 \\
$\mathrm{Zn}^{2+}$ & 8
\end{tabular}

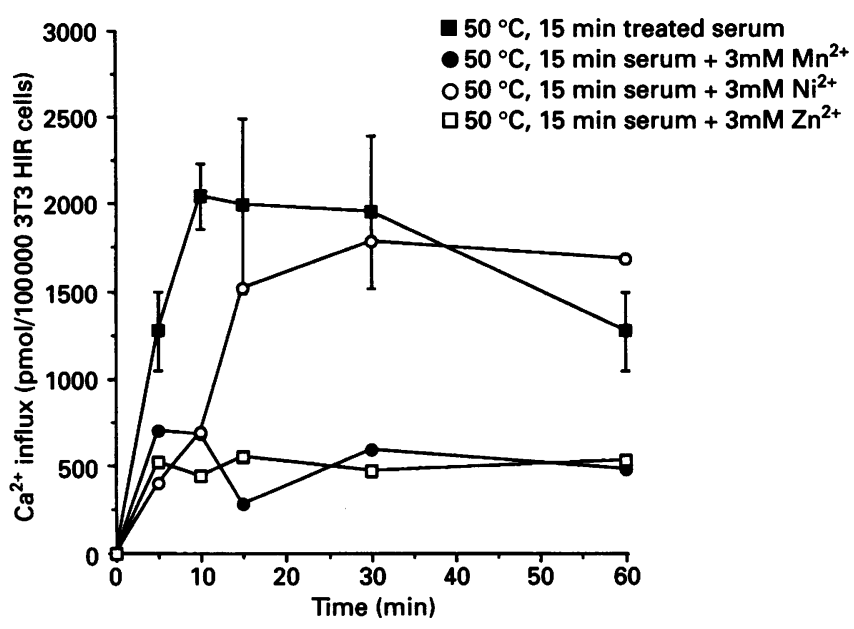

Figure 4 Effect of $\mathrm{Mn}^{2+}, \mathrm{Ni}^{2+}$ or $\mathrm{Zn}^{2+}$ or serum-induced $\mathrm{Ca}^{2+}$ influx

Antibody-coated 3Т 3 fibroblasts were incubated in the presence of 5-fold-diluted human serum treated at $50^{\circ} \mathrm{C}$ for $15 \mathrm{~min}$ to inhibit the alternative pathway of complement activation ( $\square$ ) Inorganic ions were added at a final concentration of $3 \mathrm{mM}$, and $\mathrm{Ca}^{2+}$ was always present at a final concentration of $2 \mathrm{mM}$. Methods have been previously described.

change in percentage $\mathrm{LDH}$ release on increasing $\mathrm{K}^{+}$concentration up to $17 \mathrm{mM}\left(\mathrm{Ca}^{2+}\right.$ was held constant at $\left.2 \mathrm{mM}\right)$. The result of increasing extracellular $\mathrm{K}^{+}$to $17 \mathrm{mM}$ will be to depolarize membrane potential from approx. $-100 \mathrm{mV}$ to approx. $-55 \mathrm{mV}$ (calculated from the Nernst equation), a substantial decrease but insufficient to activate endogenous voltage-gated $\mathrm{Ca}^{2+}$ channels. There was no enhancement in $\mathrm{LDH}$ release on depolarizing the resting membrane potential via altering the extracellular $\mathrm{K}^{+}$concentration, suggesting the cytolytic properties of MAC in the presence of $2 \mathrm{mM} \mathrm{Ca}^{2+}$ are not altered by membrane potential over this range.

The potency of polyvalent cations in stimulating $\mathrm{LDH}$ release were in the order: $\mathrm{Ba}^{2+}>\mathrm{Sr}^{2+}>\mathrm{Ca}^{2+}>\mathrm{La}^{3+}>\mathrm{Co}^{2+}>\mathrm{Cd}^{2+}>$ $\mathrm{Mn}^{2}>\mathrm{Ni}^{2+}>\mathrm{Zn}^{2+}>\mathrm{Cu}^{2+}$, as shown in Table 1. These data indicate the cytolytic properties of the above ions, which may result from ion and accompanying water entry into the cell via complement-dependent channel formation and subsequent colloid osmotic lysis. Ion entry is unlikely to be a result of flux via endogenous $\mathrm{Ca}^{2+}$ channels, as the potent $\mathrm{Ca}^{2+}$-channel blocker $\mathrm{La}^{3+}$ can stimulate $\mathrm{LDH}$ release to $70 \%$ of that stimulated by $\mathrm{Ca}^{2+}$.

The high concentrations of bivalent cations required for stimulation or inhibition of complement-dependent cytotoxicity argues against these profiles occurring as a result of altered $\mathrm{Clr}_{2} \mathrm{Cls}_{2}$ structure $\left(\mathrm{Ca}^{2+}\right.$ binding, which occurs at low $\mathrm{Ca}^{2+}$ concentrations, is required for this tetrameric complex formation [28]). It is a possibility that other bivalent cations may compete for $\mathrm{Ca}^{2+}$-binding sites in this structure, thus inhibiting $\mathrm{Ca}^{2+}$ binding and hence classical-pathway activation, but this argument must then be applied to all the bivalent cations studied. The results described in Table 1 demonstrate that $\mathrm{Ba}^{2+}$ and $\mathrm{Sr}^{2+}$ actually enhance cell lysis. The classical pathway of complement activation does not require either of these cations for its activity. Thus cell lysis via colloid osmotic lysis is the likely explanation for the effects of these ions on cytotoxicity. Additionally, experiments performed with Xenopus oocytes have shown that ionic currents elicited by complement can be inhibited by addition of $\mathrm{Zn}^{2+}$ after development of the inward current, ruling out $\mathrm{Zn}^{2+}$ inhibition of the early activation of the classical pathway (P. Newsholme, unpublished work).

The failure to elicit $\mathrm{LDH}$ release by $\mathrm{Mn}^{2+}$ or $\mathrm{Zn}^{2+}$ may be a consequence of blocking the complement-dependent channel or failure to elicit osmotic lysis if cell membrane penetration had been achieved. The inhibition of $\mathrm{Ca}^{2+}$ entry into 3T3 HIR cells by

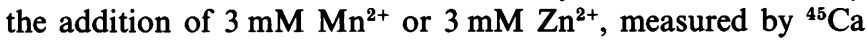
uptake, is shown in Figure 4. The results indicate that $\mathrm{Mn}^{2+}$ or $\mathrm{Zn}^{2+}$ can block the complement-dependent channel, thus inhibiting complement-elicited $\mathrm{Ca}^{2+}$ entry. At a concentration of $3 \mathrm{mM}, \mathrm{Ni}^{2+}$ only transiently blocked $\mathrm{Ca}^{2+}$ entry; $\mathrm{Ca}^{2+}$ influx approached control values at $30 \mathrm{~min}$ after serum addition. The extracellular $\mathrm{Ca}^{2+}$ concentration was maintained at $2 \mathrm{mM}$ in these latter experiments.

\section{Effect of channel modulators on ${ }^{45} \mathrm{Ca}$ entry and LDH release}

The effects of organic channel antagonists on $\mathrm{LDH}$ release are illustrated in Figure 5. The voltage-dependent L-type $\mathrm{Ca}^{2+}$ channel antagonist nifedipine [29] exhibited a concentrationdependent inhibition of LDH release at micromolar concentrations. It was not possible to use concentrations above $40 \mu \mathrm{M}$, owing to insolubility of the drug at high concentrations. Although trifluoperazine (which blocks $\mathrm{Ca}^{2+}$ entry and inhibits $\mathrm{Ca}^{2+}$ calmodulin-dependent processes) [29] was able to inhibit LDH release at $100 \mu \mathrm{M}$, the L-type $\mathrm{Ca}^{2+}$-channel antagonist verapamil [29] and the T-type $\mathrm{Ca}^{2+}$ channel antagonist phenytoin [27] actually enhanced LDH release at both 100 and $500 \mu \mathrm{M}$ concentrations. The third class of L-type $\mathrm{Ca}^{2+}$-channel antagonist, the benzothiazepine diltiazem [29] was not used in the present study, since, after $15 \mathrm{~min}$ incubation in the presence of this drug, cells no longer remained attached to the tissue-culture dish. However, up to $15 \mathrm{~min} \mathrm{Ca}^{2+}$ influx was not different from control values (results not shown).

The effect of nifedipine and verapamil on complement-stimulated ${ }^{45} \mathrm{Ca}$ influx is shown in Figure 6. There is a distinct correlation between the concentration of nifedipine needed to decrease $\mathrm{Ca}^{2+}$ influx $(40 \mu \mathrm{M})$ and that required to decrease LDH release by $42 \%$. Also, at $100 \mu \mathrm{M}$, verapamil not only enhances $\mathrm{Ca}^{2+}$ influx but also enhances LDH release, although the enhancement seen in either case is not statistically significant.

\section{Effect of $\mathrm{C9}$ depletion on ability of serum to stimulate ${ }^{45} \mathrm{Ca}$ influx}

Human serum was used to provide complement in the ${ }^{45} \mathrm{Ca}$ influx experiments, as C9-depleted human serum and purified 

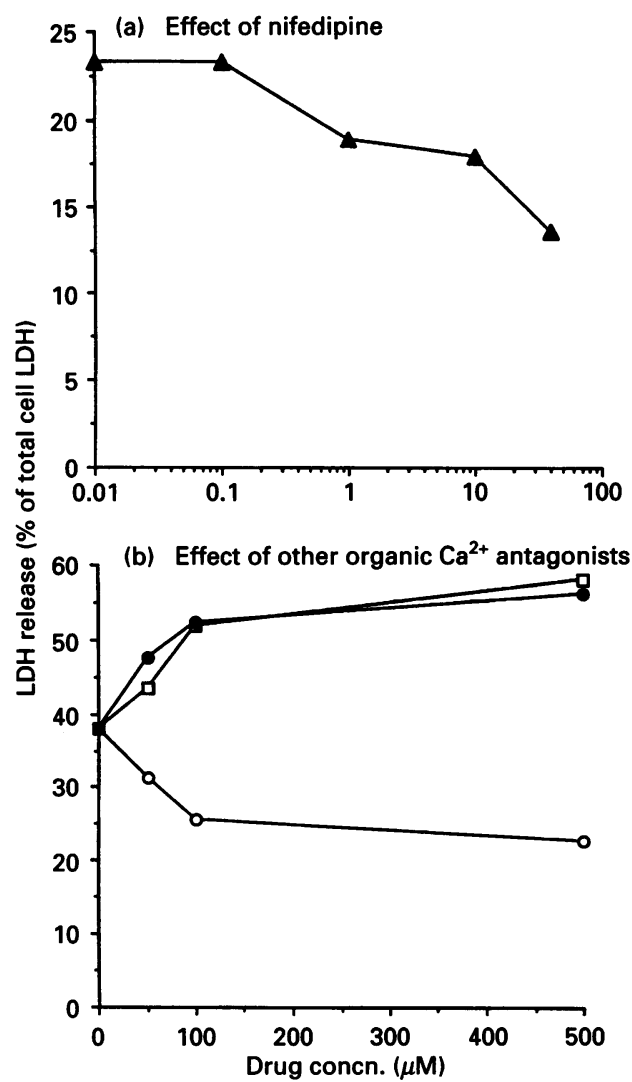

Figure 5 Dose-response of organic $\mathrm{Ca}^{2+}$ antagonists on cytotoxicity

Antibody-coated fibroblasts were incubated in a 1:5 dilution of rabbit or human serum in Hepes buffer, supplemented with different concentrations of the test agents: verapamil ( $\square$ ), trifluoperazine $(O)$, phenytoin $(O)$ and nifedipine $(\boldsymbol{A})$. The cells were incubated for $60 \mathrm{~min}$ at $37{ }^{\circ} \mathrm{C}$, and assessed for complement-dependent LDH release (S.D. of mean at each point is less than $3.5 \%$ ). The nifedipine experiment was performed with human serum, and the other drug experiments were with rabbit serum.

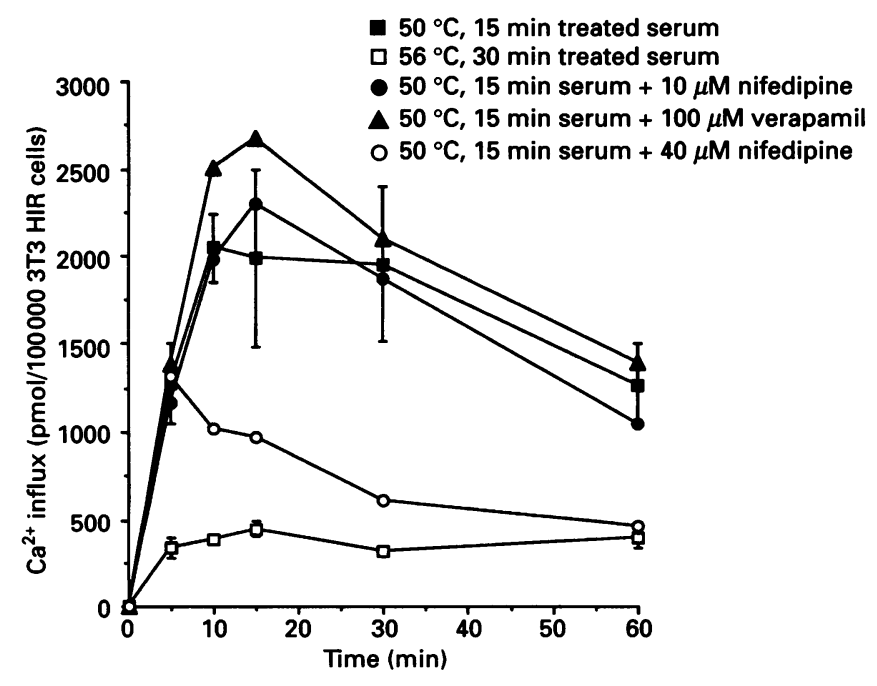

Figure 6 Effect of nlfedipine or verapamil on serum-induced $\mathrm{Ca}^{2+}$ influx

Antibody-coated $3 T 3$ fibroblasts were incubated in the presence of 5 -fold-diluted human serum treated at $50^{\circ} \mathrm{C}$ for $15 \mathrm{~min}$ to inhibit the alternative pathway $(\square)$, or at $56^{\circ} \mathrm{C}$ for $30 \mathrm{~min}$ to inhibit both complement-activation pathways $(\square)$. Nifedipine was used at 10 or $40 \mu \mathrm{M}$ and verapamil at $100 \mu \mathrm{M}$, concentrations known to inhibit endogenous $\mathrm{Ca}^{2+}$ channels.

\section{Table 2 Effect of $\mathrm{C9}$ depletion on serum-stimulated ${ }^{45} \mathrm{Ca}^{2+}$ uptake}

The incubation period for cells exposed to either whole serum or modified serum was $10 \mathrm{~min}$. Results are normalized to ${ }^{45} \mathrm{Ca}^{2+}$ uptake after $10 \mathrm{~min}$ exposure to whole serum. This value was $2.045 \mathrm{nmol}$ of $\mathrm{Ca}^{2+}$ per 1000003 T3 HIR cells. S.E.M. was less than $10 \%$ of the mean for all results shown $(n=9)$. Heating the serum for $50^{\circ} \mathrm{C}$ for $15 \mathrm{~min}$ will inactivate factor $\mathrm{B}$ and therefore the alternative pathway [25], whereas treating the serum at $56^{\circ} \mathrm{C}$ for $30 \mathrm{~min}$ will inactivate both classical and alternative pathways by denaturation of heat-labile proteins [26].

\begin{tabular}{lc}
\hline Treatment of serum (human) & Normalized ${ }^{45} \mathrm{Ca}^{2+}$ uptake \\
\hline Untreated serum & 100 \\
Serum treated at $50^{\circ} \mathrm{C}, 15 \mathrm{~min}$ & 99 \\
Serum treated at $56^{\circ} \mathrm{C}, 30 \mathrm{~min}$ & 19 \\
Serum $-C 9$ & 40 \\
Serum $-C 9,+C 9(40 \mu \mathrm{g} / \mathrm{ml})$ & 99
\end{tabular}

human C9 were available for use (a gift from Dr. J. P. Luzio [30]). The relative potency of rabbit versus human serum on LDH release is 1.4 in favour of rabbit serum. The results of an experiment performed after a $10 \mathrm{~min}$ incubation (the point at which $\mathrm{Ca}^{2+}$ influx is at a maximum) in the presence of $\mathrm{C}$ 9depleted serum and depleted serum to which $\mathrm{C} 9$ had been replaced at $40 \mu \mathrm{g} / \mathrm{ml}$ are shown in Table 2. For C9-depleted serum, it is shown that $\mathrm{Ca}^{2+}$ influx can be decreased to $40 \%$ of that stimulated by normal serum. This can be compared with $19 \%$ when complement is destroyed by treating serum at $56^{\circ} \mathrm{C}$ for $30 \mathrm{~min}$. The discrepancy arises as $\mathrm{C} 5 \mathrm{~b}-\mathrm{C} 8$ complexes have been shown to stimulate $\mathrm{Ca}^{2+}$ influx, but at a much lower rate than $\mathrm{C} 5 \mathrm{~b}-\mathrm{C} 9$ complexes [31].

\section{DISCUSSION}

The role of $\mathrm{Ca}^{2+}$ in the lytic process caused by complement activation, insertion of MAC into target cell membranes and subsequent ion flux across the membrane remains controversial. $\mathrm{Ca}^{2+}$ is absolutely required for activation of the classical pathway [28], and thus formation of MAC, but the question remains unresolved as to whether $\mathrm{Ca}^{2+}$ is required for the lytic process to proceed. Evidence has previously been presented that the early complement-generated ion flux is $\mathrm{Ca}^{2+}$-specific [8-10], though this contradicts a widely accepted view of a general ion influx followed by colloid osmotic lysis [32,33]. Morgan has presented data to show that $\mathrm{Ca}^{2+}$ influx is essential for nucleated-cell recovery from complement attack [34]. Increased cytosolic $\mathrm{Ca}^{2+}$, required for cell recovery, is only transiently increased $[10,11]$, reaching a peak after $1 \mathrm{~min}$ for neutrophils and $2 \mathrm{~min}$ for oligodendrocytes, while $\mathrm{Ca}^{2+}$ returns towards basal levels approx. $5 \mathrm{~min}$ from the initial stimulation. The present study has used ${ }^{45} \mathrm{Ca}$ as a marker to measure the influx of $\mathrm{Ca}^{2+}$ into the fibroblast cell line 3T3 HIR. The measurement of ${ }^{45} \mathrm{Ca}$ uptake unfortunately gives no indication of free cytosolic $\mathrm{Ca}^{2+}$ concentration, as a proportion of cellular $\mathrm{Ca}^{2+}$ will reside in intracellular stores such as mitochondria and the endoplasmic reticulum. However, the data presented in Figure 2 suggest that the $\mathrm{Ca}^{2+}$ concentration within the cell rises steadily after initial complement attack and reaches a peak after $10 \mathrm{~min}$. It is extremely unlikely that all the $\mathrm{Ca}^{2+}$ entering the cell will all be immediately sequestered within intracellular stores, especially as $\mathrm{Ca}^{2+}$ has been shown to be released from intracellular stores during complement attack $[10,11]$.

LDH release from the 3T3 HIR cell is indicative of breakdown of membrane integrity, to such an extent that cytoplasmic enzymes can leak out of the cell. LDH release from the 3T3 HIR 


\section{Table 3 Effect of nifedipine or verapamil on $\mathrm{K}^{+}$-stimulated ${ }^{45} \mathrm{Ca}^{2+}$ influx}

Results are normalized to the ${ }^{45} \mathrm{Ca}^{2+}$ uptake stimulated after a 10 min incubation in the presence of $30 \mathrm{mM}$ extracellular $\mathrm{K}^{+}$. This was $37.7 \%$ of that stimulated by 5 -fold-diluted human serum. S.E.M. was less than $10 \%$ of the mean value for all results shown $(n=9)$. N.D., not determined.

\begin{tabular}{cll}
\hline Concn. of drug $(\mu \mathrm{M})$ & Nifedipine & Verapamil \\
\hline $\left.0 \quad(30 \mathrm{mM} \mathrm{K})^{+}\right)$ & 100 & 100 \\
$0.1(30 \mathrm{mM} \mathrm{K})$ & 107.0 & N.D. \\
$\left.1.0(30 \mathrm{mM} \mathrm{K})^{+}\right)$ & 36.4 & 61.2 \\
$10.0(30 \mathrm{mM} \mathrm{K})$ & 25.0 & 41.6 \\
$\left.100.0(30 \mathrm{mM} \mathrm{K})^{+}\right)$ & N.D. & 23.0 \\
$0(60 \mathrm{mM} \mathrm{K})$ & 125 & 125
\end{tabular}

cell reaches a peak approx. $100 \mathrm{~min}$ after addition of serum, approx. $30 \%$ greater than $\mathrm{LDH}$ release at $60 \mathrm{~min}$ [23].

The release of $\left[{ }^{14} \mathrm{C}\right]$ sucrose from, or uptake of propidium iodide into, cells undergoing complement-stimulated cytolysis has previously been documented [35,11]. $\mathrm{Ca}^{2+}$ uptake from extracellular sources preceded membrane permeability to large molecules by approx. $15 \mathrm{~min}$ in both the cited studies. For lysis of erythrocyte ghosts [35], cell recovery mechanisms have never been documented, whereas lysis of oligodendrocytes [11] was stimulated by a concentration of serum 3 -fold that required to cause the $\mathrm{Ca}^{2+}$ transient and cell recovery via MAC removal from the membrane. Thus the higher concentration of serum required to stimulate lysis of oligodendrocytes may well have led to greater amounts of MAC being inserted into the cell membrane and possibly a longer intracellular $\mathrm{Ca}^{2+}$ transient.

The present study provides evidence that $\mathrm{Ca}^{2+}$ is essential to the lytic process initially stimulated by complement. In $\mathrm{Ca}^{2+}$-free conditions, where alternative-pathway activation can occur but the classical pathway is inhibited (EGTA present), and thus MAC can still be generated, LDH release was fully inhibited (Figure 1). Evidence that ion fluxes were generated in the absence of $\mathrm{Ca}^{2+}$ (equivalent conditions to those described for Figure 1) via activation of the alternative pathway was obtained from experiments that were designed to detect alternative-pathwaydependent ion fluxes in voltage-clamped Xenopus oocytes using electrophysiological methodology (P. Newsholme, unpublished work).

Nifedipine had an inhibitory effect on complement-dependent cytotoxicity at a concentration of $10 \mu \mathrm{M}$ (Figure 5), a concentration which does not effect complement-elicited $\mathrm{Ca}^{2+}$ influx (Figure 6). At high concentrations, nifedipine may sufficiently stabilize the membrane via a non-specific mechanism to allow cell recovery mechanisms to operate more effectively. The decrease in $\mathrm{Ca}^{2+}$ influx at $40 \mu \mathrm{M}$ nifedipine (Figure 6) may further aid cell recovery, as lower intracellular $\mathrm{Ca}^{2+}$ concentrations are less likely to stimulate cytotoxic mechanisms and are more likely to stimulate recovery mechanisms [34].

The inhibitory effects of nifedipine on complement-elicited $\mathrm{Ca}^{2+}$ influx, it may be argued, could be due to direct inhibition of endogenous $\mathrm{Ca}^{2+}$ channels which may be opened in response to plasma-membrane depolarization due to MAC-stimulated ion fluxes. However, in an experiment where 3T3 HIR cells were artificially depolarized by addition of $30 \mathrm{mM}$ extracellular $\mathrm{K}^{+}$, the ${ }^{45} \mathrm{Ca}$ influx thus stimulated was inhibited substantially by $10 \mu \mathrm{M}$ nifedipine (Table 3). Data also presented in this paper (Figure 6) shows that, at $10 \mu \mathrm{M}$ nifedipine, complement-stimulated ${ }^{45} \mathrm{Ca}$ influx is not inhibited. Also $100 \mu \mathrm{M}$ verapamil substantially inhibited $\mathrm{K}^{+}$-stimulated ${ }^{45} \mathrm{Ca}$ influx (Table 3), but did not inhibit complement-stimulated ${ }^{45} \mathrm{Ca}$ influx (Figure 6).
${ }^{45} \mathrm{Ca}$ influx stimulated by $60 \mathrm{mM}$ extracellular $\mathrm{K}^{+}$was only $47 \%$ of that stimulated by complement (Table 3). The concentration of nifedipine required to decrease cytotoxicity by approx. $50 \%$ and also to decrease $\mathrm{Ca}^{2+}$ influx in these studies was $40 \mu \mathrm{M}$ (Figure 5). This elevated concentration is above the generally accepted value for inhibition of voltage-sensitive calcium channels (10-100 nM), and other membrane activities may be altered at this concentration. However, the cell line used in these studies also had an elevated $\mathrm{IC}_{50}$ for the inhibition of endogenous $\mathrm{Ca}^{2+}$ channels $(0.6 \mu \mathrm{M}$; Table 3$)$. With Xenopus oocytes as an alternative cell for experimentation, nifedipine had an $\mathrm{IC}_{50}$ for inhibition of endogenous calcium channels of $0.1 \mu \mathrm{M}$. The $\mathrm{IC}_{50}$ was also determined for complement-elicited $\mathrm{Ca}^{2+}$ influx in the oocyte and was determined as $1.0 \mu \mathrm{M}$ (P. Newsholme, unpublished work). Complement-elicited $\mathrm{Ca}^{2+}$ influx in the oocyte was not altered by the presence of $100 \mu \mathrm{M}$ diltiazem, a concentration that was shown to inhibit endogenous $\mathrm{Ca}^{2+}$ channels fully (results not shown). Thus the evidence presented in this paper is strongly suggestive that $\mathrm{Ca}^{2+}$ influx due to complement occurs via a channel/pore that is independent of endogenous $\mathrm{Ca}^{2+}$ channels, but that shares a common property, its sensitivity to nifedipine inhibition.

The profile of ion-stimulated $\mathrm{LDH}$ release $\left(\mathrm{Ba}^{2+}>\mathrm{Sr}^{2+}>\right.$ $\left.\mathrm{Ca}^{2+}>\mathrm{La}^{3+}>\mathrm{Co}^{2+}>\mathrm{Cd}^{2+}>\mathrm{Mn}^{2+}>\mathrm{Ni}^{2+}>\mathrm{Zn}^{2+}>\mathrm{Cu}^{2+}\right)$, as documented in Table 1, is consistent with the entry of $\mathrm{Ca}^{2+}$ or other ions through a specific membrane channel/pore, rather than non-selective permeabilization (leaky patches) of the plasma membrane. As there is a low extracellular $\mathrm{Ca}^{2+}$-concentration in this experiment $(0.3 \mathrm{mM})$, cytoxicity may occur via colloid osmotic lysis caused by movement of $\mathrm{Ba}^{2+}$ or $\mathrm{Sr}^{2+}$ into the cell accompanied by water, eventually leading to cell bursting, or inhibition of cytotoxicity may occur due to block of the channel/ pore, thus avoiding osmotic changes. Other work has shown that complement-induced membrane damage may be blocked by some bivalent cations [36]. $\mathrm{Ca}^{2+}$ is less likely to be directly involved in colloid osmotic mechanisms, as it will be buffered by intracellular stores and will also be pumped out of the cell by specific plasma-membrane $\mathrm{Ca}^{2+}$ pumps [37], and thus may not reach the likely intracellular concentrations achieved by $\mathrm{Ba}^{2+}$ and $\mathrm{Sr}^{2+}$.

That the complement-induced ${ }^{45} \mathrm{Ca}$ influx is almost fully inhibited by $\mathrm{Mn}^{2+}$ and $\mathrm{Zn}^{2+}$ and partially by $\mathrm{Ni}^{2+}$ (Figure 4) indicates that the MAC channel/pore is discriminating between ions of similar ionic radii, with respect to $\mathrm{Ca}^{2+} . \mathrm{Ni}^{2+}$, however, only inhibited $\mathrm{Ca}^{2+}$ entry for $10 \mathrm{~min}$ (Figure 4), perhaps indicating a change in pore structure after this time period. This hypothesis would support that of Stanley et al. [7], in which they argue that C9 is inserted in a two-step manner, the first associated with $\mathrm{Ca}^{2+}$ influx and the second leading to $C 9$ polymerization. There is evidence that voltage-gated $\mathrm{Ca}^{2+}$ channels are potently blocked by $\mathrm{Co}^{2+}$ and $\mathrm{Ni}^{2+}$ [38], thus providing further evidence that MAC has characteristics that are not typical of endogenous $\mathrm{Ca}^{2+}$ channels, as data in this paper indicate that $\mathrm{Ni}^{2+}$ does not inhibit complement-induced $\mathrm{Ca}^{2+}$ influx, after an initial lag.

In conclusion, it appears that the lytic effects of MAC which we have observed are dependent on the presence of novel, initially $\mathrm{Ca}^{2+}$-selective, channels on the cell surface, leading to an influx of $\mathrm{Ca}^{2+}$ into the cell. These channels show little, if any, similarities to either $\mathrm{T}$ - or L-type calcium channels. The precipitous rise in intracellular $\mathrm{Ca}^{2+}$ sets in motion events leading to cell death, while over-riding protection mechanisms. The results are consistent with the hypothesis of a threshold for cell death proposed by Campbell [13]. The paradoxical role of $\mathrm{Ca}^{2+}$ stimulating recovery mechanisms and cell lytic processes has been previously discussed [31]. That paper provides evidence 
that $\mathrm{Ca}^{2+}$ is essential for complement-dependent cytotoxicity (alternative-pathway activation in the presence of EGTA did not lead to cell lysis). If physiological concentrations of extracellular $\mathrm{Ca}^{2+}$ and $\mathrm{Mg}^{2+}$ are maintained, and if the initial $\mathrm{Ca}^{2+}$ influx is inhibited by blocking agents, cytolysis is also inhibited. These results raise the possibility that drugs may be produced which specifically block the $\mathrm{Ca}^{2+}$-influx component of complement attack, with potential benefit for treatment of complementdependent diseases, e.g. multiple sclerosis, myasthenia gravis and membranous glomerulonephritis [34,39].

We thank Dr. J. Paul Luzio for provision of C9-depleted human serum and purified $\mathrm{C9}$, and for helpful comments and suggestions. This work was supported by a grant from the British Diabetic Association. P.N. was in receipt of a Medical Research Council Training Fellowship. A.A.A. was in receipt of a Foreign \& Commonwealth Office award.

\section{REFERENCES}

1 Mayer, M. M. (1972) Proc. Natl. Acad. Sci. U.S.A. 69, 2954-2958

2 Bhakdi, S. and Tranum Jensen, J. (1991) Immunol. Today 12, 318-320

3 Esser, A. F. (1991) Immunol. Today 12, 316-318

4 Shiver, J. W., Dankert, J. R. and Esser, A. F. (1991) Biophys. J. 60, 761-769

5 Young, J. D.-E. and Young T. M. (1990) Mol. Immunol. 27, 1001-1007

6 Benz, R., Schmid, A., Wiedmer, T. and Sims, P. J. (1986) J. Membr. Biol. 94, 37-45

7 Stanley, K. K., Page, M., Campbell, A. K. and Luzio, J. P. (1986) Mol. Immunol. 23, $451-458$

8 Campbell, A. K. and Luzio, J. P. (1981) Experimentia 37, 1110-1112

9 Campbell A. K., Daw, R. A., Hallet, M. B. and Luzio, J. P. (1981) Biochem. J. 194, $551-560$

10 Morgan, B. P. and Campbell, A. K. (1985) Biochem. J. 231, 205-208

11 Scolding, N. J., Houston, W. A. J., Morgan, 'B. P., Campbell, A. K. and Compston, D. A. S. (1989) Immunology 67, 441-446

12 Sims, P. J. and Wiedmer, T. (1986) Blood 68, 556-561

13 Campbell, A. K. (1983) Intracellular Calcium: Its Universal Role as a Regulator, John Wiley, Chichester
14 Chien, K. R., Abrams, J., Serroni, A., Martin, J. T. and Faber, J. L. (1978) J. Biol. Chem. 253, 4809-4817

15 Zoeteweij, J. P., Van De Water, B., De Bont, H. J. G. M., Mulder, G. J. and Nagelkerke, J. F. (1992) Biochem. J. 288, 207-213

16 Farber, J. L. (1981) Life Sci. 29, 1289-1295

17 Schanne, F. A. X., Cane, A. B., Young, E. E. and Farber, J. L. (1979) Science 206, 700-702

18 Frank, M. M., Rapp, H. J. and Boros, T. (1964) J. Immunol. 93, 409-413

19 Boyle, M. D. P., Ohanian, S. H. and Boros, T. (1976) J. Immunol. 116, 1272-1275

20 Whittaker, J., Okamoto, A. K., Thys, R., Bell, G. I., Steiner, D. F. and Hofmann, C. A. (1987) Proc. Natl. Acad. Sci. U.S.A. 84, 5237-5241

21 Soos, M. A., Siddle, K., Baron, M. D., Heward, J. M., Luzio, J. P., Bellatin, J. and Lennox, E. S. (1986) Biochem. J. 235, 199-208

22 Stanker, L. H., Vanderlaan, M. and Juarez-Salinas, H. (1985) J. Immunol. Methods 76, 157-201

23 Adogu, A. A. (1990) Ph.D. Thesis, University of Cambridge

24 Wroblewski, F. and Ladue, J. S. (1955) Proc. Soc. Exp. Biol. Med. 90, 210-215

25 Lachmann, P. J. and Hobart, M. J. (1978) Handb. Exp. Immunol. 3rd edn., vol. 1, 5A.1-5A.23

26 Cooper, N. R. (1980) In Basic and Clinical Immunology, 3rd edn. (Fudenburg, H. H., Stites, D. P., Caldwell, J. L. and Wells, J. V., eds.), pp. 119-131, Lange Medical Publications, Los Altos, CA

27 Porzig, H. (1990) Rev. Physiol. Biochem. Pharmacol. 114, 210-262

28 Reid, K. B. M. (1986) Essays Biochem. 22, 27-68

29 Godfraind, T., Miller, R. and Wibo, M. (1986) Pharmacol. Rev. 38, 321-393

30 Morgan, P. B., Daw, R. A., Siddle, K., Luzio, J. P. and Campbell, A. K. (1983) J. Immunol. Methods 64, 269-281

31 Morgan, B. P., Luzio, J. P. and Campbell, A. K. (1986) Cell Calcium 7, 399-411

32 Green, H., Barrow, P. and Goldberg, B. (1959) J. Exp. Med. 110, 699-705

33 Mayer, M. M. (1977) J. Immunol. 119, 1195-1203

34 Morgan, B. P. (1989) Biochem. J. 264, 1-14

35 Morgan, B. P., Luzio, J. P. and Campbell, A. K. (1984) Biochem. Biophys. Res. Commun. 118, 616-622

36 Bashford, C. L., Alder, G. M., Menestrina, G., Micklem, K. J., Murphy, J. J. and Pasternak, C. A. (1986) J. Biol. Chem. 261, 9300-9307

37 Tepikin, A. V., Voronina, S. G., Gallacher, D. V. and Petersen, O. H. (1992) J. Biol. Chem. 267, 14073-14076

38 Winegar, B. D., Kelly, R. and Lansman, J. B (1991) J. Gen. Physiol. 97, 351-355

39 Linington, C., Morgan, B. P., Scolding, N. J., Wilkins, P., Piddlesden, S. and Compston, D. A. S. (1989) Brain 112, 895-900

Received 15 February 1993/1 June 1993; accepted 9 June 1993 